\title{
Developing Stakeholder Engagement for Infrastructure Projects
}

\section{Case Study on Indonesia Infrastructure Roundtable/IRR}

\author{
Ratna Widianingrum \\ PT Penjaminan Infrastruktur Indonesia (Persero) \\ Corresponding author: \\ w.ratna@iigf.co.id
}

\begin{abstract}
The relatively high economic growth leads to an increase in infrastructure needs in Indonesia. Providing these needs for infrastructure has an irreplaceable role in improving the overall quality of life of the population, therefore its success requires support and commitment from various stakeholder groups. In the context of the support, a concept to approach the stakeholders is known as stakeholder engagement. The objective of this research is to measure the effectiveness of a program in affecting the condition of stakeholders, and in developing the stakeholder engagement which will directly determine the success of infrastructure development. This study was conducted using a qualitative descriptive method through case study approach to observe the relationship between the use of stakeholder-involvement program and the level of stakeholder engagement. The results show that the quality of activities (procedural quality, responsiveness quality, quality of outcomes) shows relatively good results with a middle-level involvement. It will require more activities to trigger a more intense relationships and to increase the level of stakeholder engagement in providing their support for infrastructure development.
\end{abstract}

Keywords: stakeholder, stakeholder engagement; infrastructure development

SARI PATI

Pertumbuhan ekonomi yang relatif tinggi menyebabkan meningkatnya kebutuhan infrastruktur di Indonesia. Pemenuhan kebutuhan akan infrastruktur tersebut memiliki peranan penting dalam peningkatan kualitas hidup dan kesejahteraan manusia, sehingga keberhasilannya memerlukan dukungan dan komitmen dari berbagai kelompok-kelompok yang berkepentingan (stakeholder). Dalam konteks dukungan tersebut kemudian dikenal sebuah konsep pendekatan terhadap stakeholder yang dikenal dengan istilah stakeholder engagament. Tujuan dari penelitian ini adalah untuk mengetahui seberapa baik sebuah program dalam mempengaruhi kondisi pemangku kepentingan, membangun terbentuknya stakeholder engagement yang akan ikut menentukan keberhasilan pembangunan infrastruktur. Penelitian ini dilakukan dengan metode deskriptif kualitatif melalui pendekatan studi kasus untuk meneliti hubungan antara penggunaan bentuk program yang melibatkan para pemangku kepentingan terhadap tingkat keterlibatan para pemangku kepentingan. Hasil penilaian menunjukkan bahwa kualitas kegiatan (procedural quality, responsiveness quality, quality of outcomes) menunjukkan hasil yang relatif baik dengan level keterlibatan menengah (middle). Diperlukan kegiatan-kegiatan pemicu yang dapat mengikat dalam hubungan yang lebih intens serta meningkatkan level keterlibatan para pemangku kepentingan dalam memberikan dukungannya terhadap pembangunan infrastruktur.

Kata Kunci: stakeholder, stakeholder engagement; pembangunan infrastruktur

Copyright (C) 2018, Journal of Infrastructure Policy and Management 


\section{INTRODUCTION}

An important factor that plays a role in a successful infrastructure development project is the active support of the project stakeholders. This support can be gained by employing stakeholder management techniques that will involve multiple parties through ways that can enhance collaboration among them. In managing relationships with stakeholders, the main focus lies in communication as the major tool in building and maintaining relationships with related parties. Communications and good relationships established with stakeholders under any circumstances play a very important role in the sustainability of the project and the organization itself. Therefore any error in communication management and strategy may hurt the organization as its stakeholders may consist of various pressure groups that must be considered by the organization (Emshoff, 1987: 138). In this context, in addition to its basic function to maintain the image of the organization in the public eye, communication also serves to establish relationships with stakeholders in order to retain a steady performance of the organization or in this context to ensure the role of stakeholders in the project success. The more power that the stakeholders hold, the greater the impact it will impose on the success of the program. Nguyen et al. (2009) in Chandra et.al (2011) states that as the impact of stakeholders grows bigger, the success of the program will depend on how to meet the expectations of all relevant stakeholders. Therefore the management of stakeholder management will the key to the success of the organization. The company's accuracy to engage, manage, utilize, and communicate with every stakeholder effectively will help to achieve all the goals and plans of the company as expected.

External communication then becomes some sort of instrument in developing what is called stakeholder engagement, which is a series of planned and implemented activities in order to gain recognition, acceptance and sustainability of relationships between companies and stakeholders. Stakeholder engagement can facilitate organizations to identify the needs of stakeholders (Isenmann, 2006). One of the theories on strategies used in communication with stakeholders is the Proactive Strategy, which employs audience engagement or audience participation in order to build stakeholder engagement.

The use of audience engagement activity in the form of audience participation is widely used in two-way dialogue format. Dialogue is preferred as it is considered effective, since the response can be directly observed both verbally and non-verbally. Therefore if the given response or feedback is positive, the message can be received clearly by the participants/ speakers and similarly we can also give similar response. This form of activity then became a popular notion within stakeholder relations, as it was perceived to have a better understanding effect amidst the complexity of the relationships between stakeholders and the various conflicts of interest that might take place. The relationships that occurred when developing organizational strategy to establish communication with stakeholders within the context of stakeholder engagement have presented research questions such as: a) What is the stakeholder communication strategy in the dialogue activities? b) How stakeholder engagement is established within the dialogue activities?

This research uses qualitative methods which are expected to reveal what elements in the stakeholder communication program that mutually influence the level of stakeholder involvement in an organization's activities. Research on stakeholder engagement is currently dominated by quantitative methods that aim to measure the level of stakeholder engagement in causal relationships between 
various variables thus a different method is expected to identify other processes that might have not been measured. The results may be applied elsewhere, as long as the conditions remain rather similar to the current place of research.

This research will also contribute to the progress of communication theory, especially on the theory of stakeholder engagement. Earlier theory has mentioned the elements in establishing stakeholder engagement, but for further development this research will highlight the most influential elements in its formation. The measurement of the level of stakeholder involvement in this study is conducted using the ladder of stakeholder management and stakeholder engagement theory developed by Friedman (2006) which has not been widely applied in the research on similar subject. The results of this study show that the relationship between the program's format in use (audience engagement) with the level of stakeholder engagement, is influenced by the presence of elements in the audience engagement. In addition this research will also observe the phenomenon of dialogue, which is different from previous research and shows a positive and supportive outcome in the development of stakeholder engagement.

\section{THEORETICAL STUDY}

\section{Stakeholder Management}

One of the most relevant basic concepts to use in assessing an organization's relationship with other parties is the stakeholder concept, which uses a stakeholder approach in identifying groups that may bring influences to the organization. This approach was then developed to assist organizations in planning a stakeholder map by categorizing key people or parties to be managed and be closely followed up. Freeman and McVea (2001) state that in the perspective of stakeholders, this main activity is called stakeholder management. Yang et al., (2011) then identifies stakeholder management as a process of identifying, analyzing, communicating, making decisions and activities within the framework of managing stakeholders. The core of this process is to actively manage and integrate stakeholder relationships and interests which consist of following phases: stakeholder identification, stakeholder analysis, stakeholder communication and stakeholder engagement.

Bourne (2010) adds several categories in the stages of stakeholder analysis which he called The Stakeholder Circle. The Stakeholder Circle consists of the following steps: identification of all stakeholders, categorization of priority stakeholders, stakeholder mapping to understand the stakeholders as a whole, engagement through effective communication and the last is continuous monitoring on the effectiveness of the actual communication program.

\section{Organization Proactive Strategy}

In order to achieve its vision and mission, an organization at its early stage, will analyze the ongoing strategic issues. The results shall become the basis in setting organizational strategy. Effendy (2003:35) states that it would be ideal if the strategy considers all communication components and the supporting/inhibiting factors on each component. In addition, the success of a corporate communications strategy will depend largely on how closely the communication strategy is linked to the overall business strategy (Clutterbuck, 2001: 30). Therefore, when developing its grand strategy, an organization will need to take account of its corporate communication efforts as manifested in its vision and mission statement.

Given that communication is a complicated process, it will require a coherent communication strategy in its implementation. Effective communication includes appropriate actions and statements, therefore a strategic communication planner shall have profuse options of action 


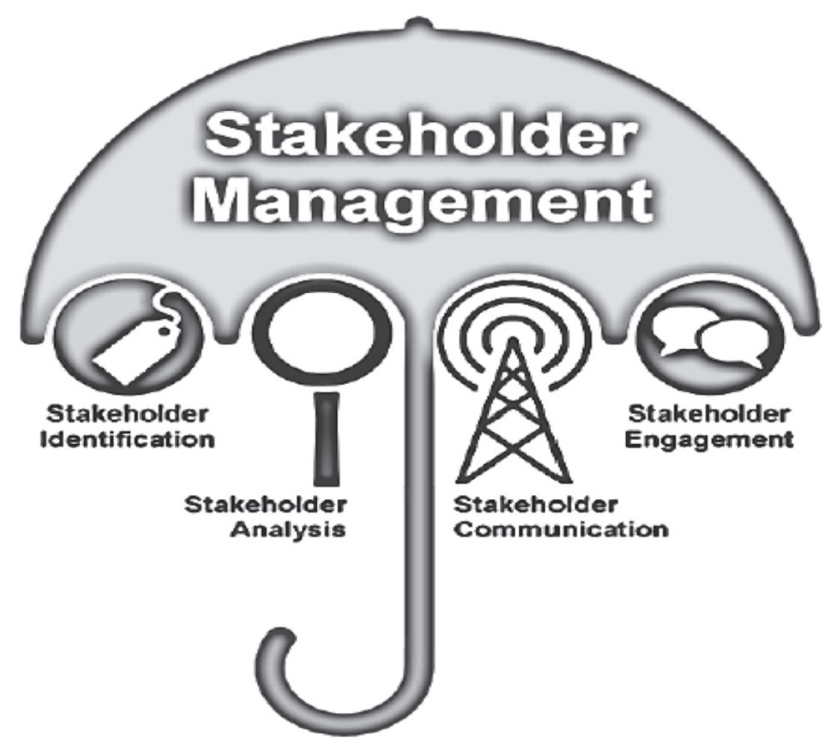

Figure 1: Stakeholder Management (Stakeholder Engagement for Major Projects Forum, 2014)

followed by suitable statements, through a proactive and reactive strategy. According to Smith (2013:113), a proactive strategy is an approach that enables an organization to start a communication program at the right time and condition in accordance with the interests of the organization. It shall all the required action and communication. This strategy becomes the underlying choice for the implementation of activities in this research.

\section{Stakeholder Communication Strategy - \\ Audience Engagement}

In formulating the organization's action plan and response strategy to public relations, Smith (2013: 114) divides communication strategies into a proactive typology: organizational performance, audience engagement, special events, alliance and coalitions, sponsorships, strategic philanthropy and activism. This action strategy is a concrete action that the organization is undertaking in an effort to achieve the organizational goals. Program activity in this research (audience engagement activity) is a form of tactical program from the implementation of organization proactive strategy. In this strategy there are 4 (four) elements that form the audience engagement: the first is the Audience Interest, which is a form of audience involvement by communicating the interests of the relevant audience. The formal form for this is the accuracy of information that is the level at which the information can be applied or useful to the IIR participants.

The second is Audience Participation, which is a form of audience involvement by increasing the participation of IIR audience by providing feedback. This takes places by creating a comfortable way for the audience to respond to a message and to participate in the IIR dialogue. The third is Audience Feedback, which is a form of audience involvement by encouraging public participation, i.e. by collecting feedback. This aims to provide a suitable environment for the IIR audience to be able to respond to organizational messages and engage in the dialogue. The technique employed here is the Q\&A session. The fourth and the last one is Triggering Events, which is a form of audience engagement through events that will trigger the creation of bonds among the stakeholders. 
Triggering events may take form in both planned and unplanned activity, and shall have the objective to quickly seize the opportunity to highlight the organization and to be focus on certain issues.

\section{Stakeholder Engagement}

Stakeholder engagement refers to the process in which organizations involve their stakeholders in the decision-making process. According to Sugihantoro (2014), the initial definition of stakeholder management portrays a process and control that must be planned using a fundamental principle, in order to gain a level of commitment from stakeholders that will support the achievement of a project or a business objective. From this definition it is understood that stakeholder engagement is a process that must be undertaken in order to achieve the organization's main goal.

Friedman (2006) then defines stakeholder engagement as the process of effectively eliciting stakeholder views on their relationship with the organization/program/project. This process is used by organizations to engage relevant stakeholders in achieving an acceptable result. Engagement itself is not the objective, but an instrument to form better relationship with the communities in which an organization operates. Stakeholder engagement helps their participation in the organization's business management by sharing information and creating a model with shared responsibilities (Manetti, 2011).

Isenmann and Kim (2006) state that in this case, stakeholder engagement can facilitate the organization to identify the expectation of the stakeholders and to gain recognition, acceptance and sustainability of relationships between the organization and its stakeholders. If stakeholder management refers to activities that resemble a persuasive strategy, then the stakeholder engagement more closely resembles a dialog strategy. Stakeholder engagement refers to the process in which the organizations engage stakeholders in the organization's decisionmaking process, enabling them to participate in business management by sharing information and creating a model of shared responsibilities.

\section{Quality of Stakeholder Engagement}

To clarify the concept of measurement in this study, the researcher will take two main parameters when observing the level of stakeholder engagement, i.e. quality of stakeholder engagement and the ladder of stakeholder management and engagement. The first parameter in this study was developed by Zadek and Raynard (2002) by looking at 3 (three) dimensions of quality engagement: The first is Procedural Quality, which refers to the quality of how the engagement is done and whether the engagement is conducted consistently with the stated objectives.

The second is Responsiveness Quality, which refers to how a company cope and respond to issues raised by stakeholders. The quality of responsiveness can be evaluated by analyzing whether the organization fully understands the concerns of stakeholders and whether the issues are raised and delegated to decision-makers relevant to the organization. The third is Quality Outcomes, referring to the visible evidence of whether organizations adjust the organization's policies and practices to align with stakeholder engagement. Stakeholder satisfaction also indicates the level of outcomes quality generated. Quality stakeholder engagement should includes stakeholders in an active and meaningful way, which can be linked to decision making process within the organization.

\section{The Ladder of Stakeholder Management and} Engagement

This model was developed by Friedman and Miles (2006) which is a modified version of Arnstein's Ladder and then developed into a 
model to analyze the quality level of stakeholder management and engagement practices. This model is developed to outline the ladder of stakeholder management and engagement which consist of 12 different levels: (1) Level 1 and 2: Manipulation and Therapy (2) Level 3:
Informing (3) Level 4: Explaining (4) Level 5: Placation (5) Level 6: Consultation (6) Level 7: Negotiation (7) Level 8: Involvement (9) Level 9: Collaboration (10) Level 10: Partnerships (11) Level 11: Delegated power (12) Level 12: Stakeholder control.

Table 1. A Ladder of Stakeholder Management and Engagement (Friedman, 2006)

\begin{tabular}{|c|c|c|c|c|c|}
\hline & & $\begin{array}{l}\text { Stakeholder } \\
\text { management tool ands } \\
\text { nature of response }\end{array}$ & $\begin{array}{l}\text { Intention of } \\
\text { engagement }\end{array}$ & $\begin{array}{l}\text { Level of } \\
\text { influence }\end{array}$ & $\begin{array}{l}\text { Style of dialogue and } \\
\text { associated examples }\end{array}$ \\
\hline \multirow[t]{3}{*}{$\begin{array}{l}\text { Degrees of } \\
\text { stakeholder } \\
\text { power }\end{array}$} & \multirow{5}{*}{$\begin{array}{l}\text { Proactive or } \\
\text { responsive/ } \\
\text { trusting }\end{array}$} & $\begin{array}{l}\text { 12. Stakeholder } \\
\text { control }\end{array}$ & $\begin{array}{c}\text { Majority } \\
\text { representation of } \\
\text { stakeholders in } \\
\text { decision-making } \\
\text { process }\end{array}$ & \multirow{4}{*}{$\begin{array}{l}\text { Forming or } \\
\text { agreeing to } \\
\text { decisions }\end{array}$} & $\begin{array}{l}\text { Multi-way dialogue } \\
\text { e.g. community } \\
\text { projects }\end{array}$ \\
\hline & & 11. Delegated power & $\begin{array}{c}\text { Minority } \\
\text { representation of } \\
\text { stakeholders in } \\
\text { decision-making } \\
\text { process }\end{array}$ & & $\begin{array}{l}\text { Multi-way dialogue } \\
\text { e.g. board } \\
\text { representation }\end{array}$ \\
\hline & & 10. Partnership & $\begin{array}{l}\text { Joint decision- } \\
\text { making power over } \\
\text { specific projects }\end{array}$ & & $\begin{array}{l}\text { Multi-way dialogue } \\
\text { e.g. joint ventures }\end{array}$ \\
\hline \multirow{2}{*}{$\begin{array}{l}\text { Degrees of } \\
\text { involvement }\end{array}$} & & 9. Collaboration & $\begin{array}{l}\text { Some decision- } \\
\text { making power } \\
\text { afforded to } \\
\text { stakeholders over } \\
\text { specific projects }\end{array}$ & & $\begin{array}{l}\text { Multi-way dialogue } \\
\text { e.g. strategic alliances }\end{array}$ \\
\hline & & 8.Involvement & \multirow{2}{*}{$\begin{array}{l}\text { Stakeholders } \\
\text { provide conditional } \\
\text { support; if conditions } \\
\text { are not met support } \\
\text { is removed. The } \\
\text { organisation decides } \\
\text { the extent of the } \\
\text { conformity }\end{array}$} & \multirow{2}{*}{$\begin{array}{l}\text { Having an } \\
\text { influence on } \\
\text { decisions }\end{array}$} & $\begin{array}{l}\text { Multi-way dialogue } \\
\text { e.g. constructive } \\
\text { dialogue }\end{array}$ \\
\hline \multirow{4}{*}{$\begin{array}{l}\text { Degrees of } \\
\text { tokenism }\end{array}$} & \multirow{4}{*}{$\begin{array}{l}\text { Responsive/neut } \\
\text { ral }\end{array}$} & 7. Negotiation & & & $\begin{array}{l}\text { Multi-way dialogue } \\
\text { e.g. reactive } \\
\text { bargaining }\end{array}$ \\
\hline & & 6. Consultation & $\begin{array}{l}\text { Organisation has the } \\
\text { right to decide. } \\
\text { Stakeholders can } \\
\text { advise. Appease the } \\
\text { stakeholder }\end{array}$ & \multirow[b]{2}{*}{$\begin{array}{l}\text { Being heard } \\
\text { before a } \\
\text { decision }\end{array}$} & \multirow{2}{*}{$\begin{array}{l}\text { Two-way dialogue e.g. } \\
\text { questionnaires, } \\
\text { interviews, focus } \\
\text { groups, task forces, } \\
\text { advisory panels }\end{array}$} \\
\hline & & 5. Placation & $\begin{array}{l}\text { Stakeholders can } \\
\text { hear and be heard } \\
\text { but have no } \\
\text { assurance of being } \\
\text { heeded by the } \\
\text { organisation }\end{array}$ & & \\
\hline & & 4. Explaining & \multirow{2}{*}{$\begin{array}{c}\text { Educate } \\
\text { stakeholders }\end{array}$} & \multirow{4}{*}{$\begin{array}{l}\text { Knowledge } \\
\text { about decisions }\end{array}$} & $\begin{array}{l}\text { Two-way dialogue e.g. } \\
\text { workshops }\end{array}$ \\
\hline \multirow{3}{*}{$\begin{array}{l}\text { Non- } \\
\text { participation }\end{array}$} & \multirow{3}{*}{$\begin{array}{l}\text { Autocratic/ } \\
\text { cynical }\end{array}$} & 3. Informing & & & $\begin{array}{l}\text { One-way dialogue e.g. } \\
\text { verified corporate } \\
\text { reports }\end{array}$ \\
\hline & & 2. Therapy & $\begin{array}{l}\text { 'Cure' stakeholders } \\
\text { of their ignorance } \\
\text { and preconceived } \\
\text { beliefs }\end{array}$ & & \multirow[t]{2}{*}{$\begin{array}{l}\text { One-way dialogue, } \\
\text { e.g. briefing sessions, } \\
\text { leaflets, magazines, } \\
\text { newsletters, corporate } \\
\text { reports other } \\
\text { publications }\end{array}$} \\
\hline & & 1. Manipulation & $\begin{array}{l}\text { 'Misleading' } \\
\text { stakeholders, } \\
\text { attempting to } \\
\text { change stakeholder } \\
\text { expectations }\end{array}$ & & \\
\hline
\end{tabular}




\section{METHODS}

This research uses a post-positivism paradigm to combine logical thinking and logical observation to predict the general pattern of symptoms or phenomena concerning the four elements in a proactive communication strategy of audience engagement stakeholder, i.e. audience interest, audience participation, audience feedback, and triggering events. The questions to be answered are: how these four elements can build stakeholder engagement, what is the quality of stakeholder engagement and on what level stakeholder engagement is formed. The respondents are the participants of 14th Indonesia Infrastructure Roundtable (IRR) held on August 15, 2016 in Malang. The participants shall represent the stakeholders of PT PII from various elements. Case study method shall be used in this research which will use various data source. Data will be collected through interview and qualitative analysis shall be used with three types of data analysis process (coding): open coding, axial coding and selective coding.

\section{Operational Research Framework}

This research uses post-positivism paradigm so that operationalization of the concept will be a model development based on theory and concept. In this research, the operationalization of the concept is based on the operational theory and definition of each research variable.

\section{RESULT AND DISCUSSION}

\section{Stakeholder Identification}

Stakeholders of PT PII are defined as parties/ institutions that may affect and/or be affected by the project realization process under the PPP scheme of PT PII. An institution/party is said influential if this institution/party can impede, fail, or on the other hand accelerate the realization of PT PII's collateral on an infrastructure development project using the PPP scheme.

From the documents collected by the researchers, those who fall into the category of stakeholders of PT PII are the parties in charge for the cooperation projects (penanggung jawab proyek

Table 2. Concept Operationalization

\begin{tabular}{|l|l|l|}
\hline Dimensi & Scope of Analysis & Source of Data \\
\hline Idakntification & $\begin{array}{l}\text { A stakeholder identification which } \\
\text { includes understanding the issues } \\
\text { encountered by the company and } \\
\text { the type and characteristics of } \\
\text { stakeholders }\end{array}$ & $\begin{array}{l}\text { Documents, literature studies } \\
\text { and interviews }\end{array}$ \\
\hline Stakeholder Analysis & $\begin{array}{l}\text { Prioritization and mapping of the } \\
\text { functions, roles and contributions of } \\
\text { stakeholders in accordance with the } \\
\text { operational needs of the organization. }\end{array}$ & $\begin{array}{l}\text { Documents, literature studies } \\
\text { and interviews }\end{array}$ \\
\hline Stakeholder & $\begin{array}{l}\text { Preparation of communication plans } \\
\text { targeted to stakeholders. The use } \\
\text { of proactive strategy in stakeholder } \\
\text { communication program - audience } \\
\text { engagement }\end{array}$ & $\begin{array}{l}\text { Documents, literature studies } \\
\text { and interviews }\end{array}$ \\
\hline $\begin{array}{l}\text { Stakeholder } \\
\text { Engagement }\end{array}$ & $\begin{array}{l}\text { Monitoring of all the qualities of } \\
\text { processes already undertaken } \\
\text { within the stakeholder engagement } \\
\text { assessment of the quality of } \\
\text { engagement and the rank or level of } \\
\text { stakeholder engagement }\end{array}$ & $\begin{array}{l}\text { Documents, literature studies } \\
\text { and interviews }\end{array}$ \\
\hline
\end{tabular}


kerjasama/PJPK) coming from government institutions and BUMN/BUMD, the government of the Republic of Indonesia i.e. the ministry institutions, investors, creditors, political groups (DPR, DPRD), non-PJPK local government, expert \& opinion leader, community around the project, universities and internal PT PII.

\section{Stakeholder Analysis-Prioritization}

This stakeholder identification is then followed up with an analysis on the stakeholders that may affect or be affected by the completion of PT PII's collateral process. These stakeholders can be categorized into 4 (four) major groups: 1) Stakeholders with a very good relationship, 2) Stakeholder with a good relationship. 3) Stakeholder with relatively unmaintained relationship and 4) Stakeholder with no existing relationship.

\section{Stakeholder Analysis - Mapping}

From the stakeholder identification result, the researcher then conducted stakeholder mapping of PT PII based on the highest order of importance. The classification is ring 1, ring 2 , ring 3 and ring 4 being the farthest one (see Figure 3).
The participants of this research activity consist of various elements representing the stakeholders of PT PII which either directly or indirectly involved in the development process of Pandaan-Malang Toll Road project as follows (see Table 3).

\section{Stakeholder Communication}

The strategy used in this research is communication strategy for stakeholderaudience engagement. It takes form of a twoway dialogue format that engages the audience as well as the community. The participants actively communicate their interests related to the theme of the discussion, in a far bigger portion than PT PII communicating its interest as the sponsor of this activity. The measurement of audience involvement is marked in a formal form as the accuracy of the information, i.e. the degree to which information can be applied or useful to the audience.

Among the four elements within the audience engagement (audience interest, audience participation, audience feedback and triggering events) all the participants agreed that the first three elements have been sufficient. The

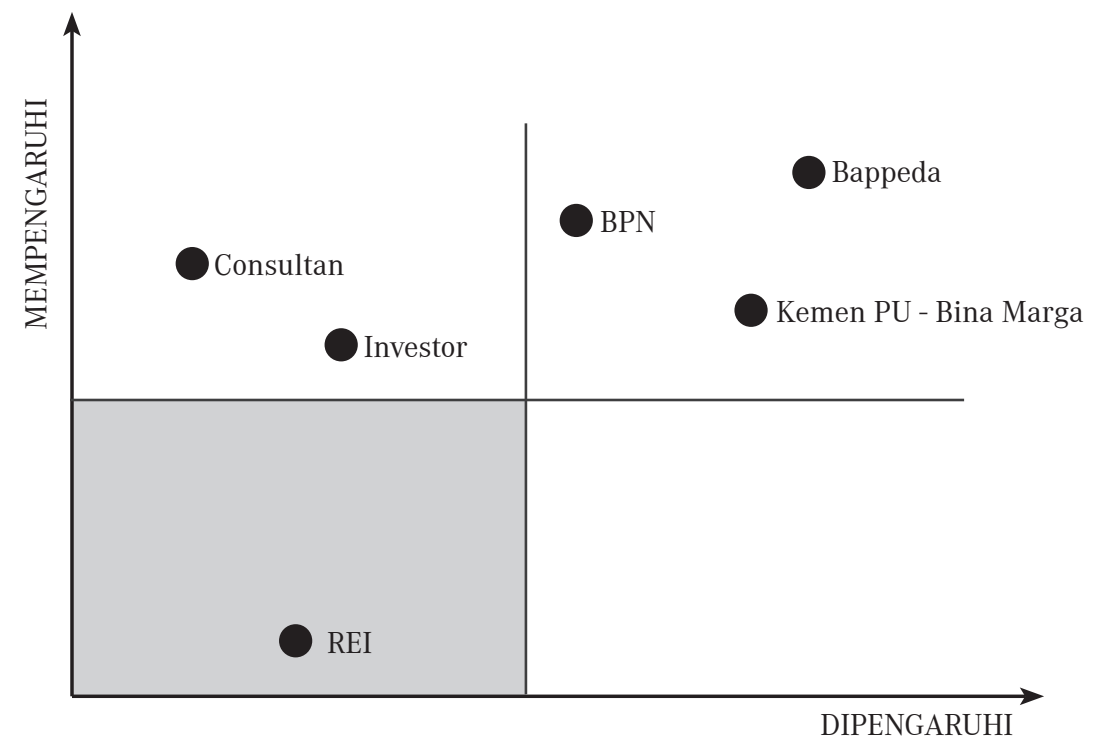

Figure 2: Positioning of PT PII's Stakeholder 


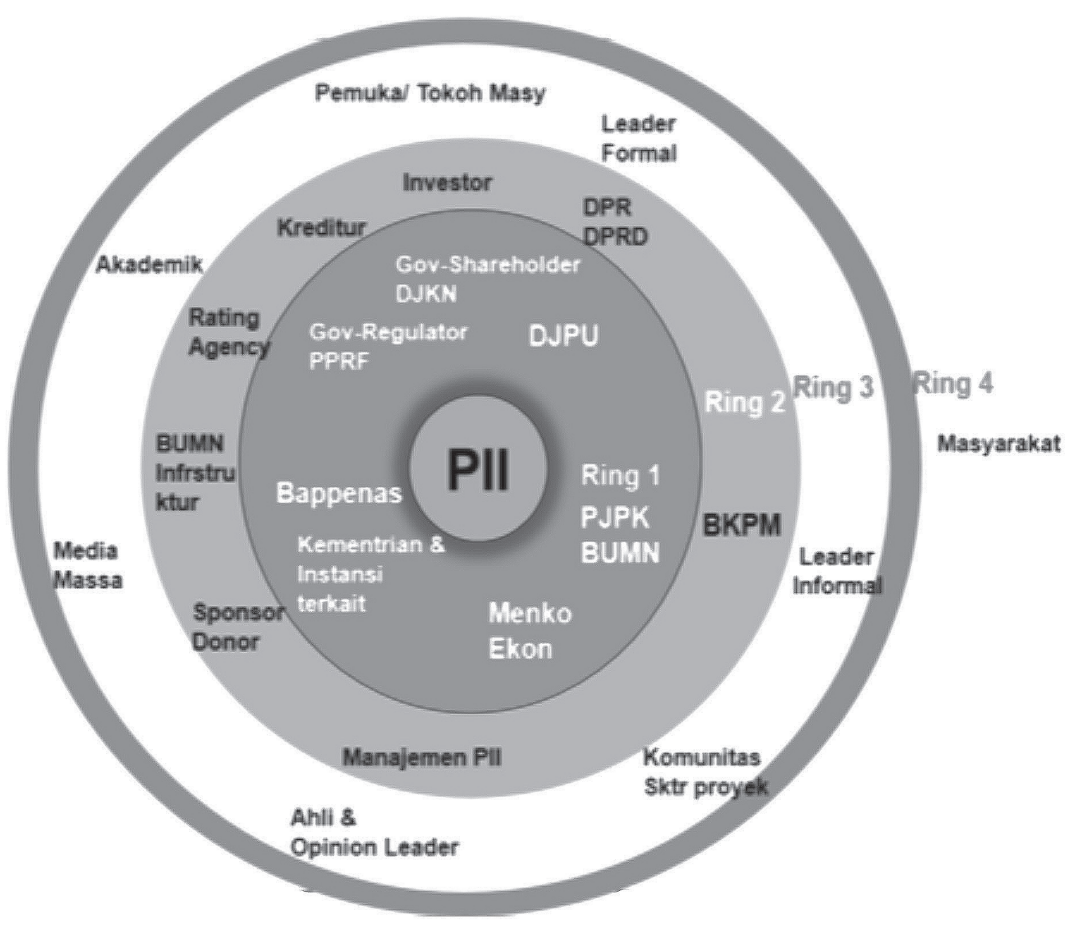

Figure 3: Stakeholder Mapping of PT PII

Table 3. Stakeholder Mapping

\begin{tabular}{|c|c|c|}
\hline Stakeholder Ring 1 & $\begin{array}{l}\text { Ministries and related } \\
\text { institutions, BUMN, PJPK }\end{array}$ & $\begin{array}{l}\text { Head of Public Works Office Bina } \\
\text { Marga, Head of Regional Development } \\
\text { Planning Agency/ Bappeda (of East Java } \\
\text { Province); Head of Bappeda, Head of } \\
\text { Department of Transportation, Head of } \\
\text { Public Work and Public Housing/PUPB } \\
\text { Office, Head of National Land Agency/ } \\
\text { BPN (of Municipality of Malang); Head } \\
\text { of Bappeda, Head of Department of } \\
\text { Transportation, Head of Public Works } \\
\text { Office, Head of BPN (of Regency of } \\
\text { Malang), Director of PT. Sarana Multi } \\
\text { Infrastruktur }\end{array}$ \\
\hline Stakeholder Ring 2 & $\begin{array}{l}\text { Financier/Financing } \\
\text { institution }\end{array}$ & PT Bank BNI 1946 (Persero) \\
\hline Stakeholder Ring 3 & $\begin{array}{l}\text { Community and experts in } \\
\text { their field }\end{array}$ & $\begin{array}{l}\text { Dirlantas Polda Jatim (Directorate } \\
\text { of Traffic, Police Office of East Java } \\
\text { Province); Brawijaya University, } \\
\text { Technical Consultant of Widyagama } \\
\text { University of Malang, Transportation } \\
\text { Observer, Head of Toll Road Association/ } \\
\text { AJT, Chairman of Real Estate Indonesia } \\
\text { (REI) of East Java, Commissioner } \\
\text { of Malang, Chairman of Organda } \\
\text { (Organization of Public Transport) of } \\
\text { Malang }\end{array}$ \\
\hline
\end{tabular}


result shows that IIR activities are very useful, where the participants actively responded to the messages and there were positive feedback to the organizer on their participation. Only the last element (triggering event) was lacking, although basically the organizers have prepared this form of a triggering event, however the participants' lack of information and the absence of a real invitation to this matter made this element still unfulfilled.

\section{Stakeholder Engagement}

Assessment of stakeholder engagement is undertaken on the quality dimension that can lead to the realization of stakeholder engagement and asses on the level of stakeholder engagement. The first quality dimension is procedural quality. The invited stakeholders are selected in a neutral and unbiased manner. Therefore procedural quality can be deemed satisfactory. As for the responsiveness quality dimension, all the participants give a positive statement on the responsiveness of the organizers in handling and responding to the issues raised by the participants. For the dimension of quality outcomes, it may be concluded that all participants feel quite involved in the decision making and that their comments are also well received by other participants.

The evaluation of stakeholder engagement level is based on 2 (two) variables: intention of engagement and level of influence. This evaluation has identified 2 (two) main reasons of intention/interest of the participants in attending this IIR event: the participants want to broaden their knowledge that can be based on their interest in IIR events and theme of IIR, and the participants want to know the opinions of others and to give their own opinions in return.

\section{Discussion and Analysis}

The initial stage of stakeholder management is carried out by the organizers through an initial screening, in which the invited IRR participants and speakers are directly influencing or being influenced by PT PII and having a high to moderate level (2-4) in terms of power, proximity and urgency elements. They also represent the elements of stakeholders in ring 1, 2 and 3. The most important external stakeholders for PT PII are the project owner or in this case PJPK and the local government (Pemda). However both stakeholders have a very heterogeneous profiles that may differ depending on the type of ongoing project.

There are four steps undertaken by stakeholders in the audience engagement within this IIR activity: audience interest, audience participation, audience feedback and triggering events. The first three elements according to the results have been acceptable, except for the fourth element (triggering events). As for the results of research on 3 (three) dimensions of the stakeholder engagement quality category: 1 ) procedural quality through the implementation of IIR engagement activities is consistent with the objectives; 2) responsiveness quality is observed from how all participants felt quite involved and having their opinion listened in the decision-making forums and 3) quality outcomes is seen from all the participants who stated that their outcomes and opinions that they provided gave a certain influence to the forum although not yet at the policy level and in terms of quality will affect the organizational decision-making process.

The results of the research indicate the level of intention engagement is currently at 3 (three) middle level: level 4 (explaining) which is to educate stakeholders, level 5 (placation): stakeholders can listen and be listened but not guaranteed to be noticed by the organization and level 6 (consultation): the organization has the right to decide, stakeholders can suggest, which will provide assurance to the stakeholders. This shows that the engagement formed in the IIR activities is still in the awareness stage which 
has led to the emergence of engagement in the form of the right to provide opinion, despite the full control still remains under the hand of the organization. This means that what is conveyed within the forum is still limited to the proposed opinion and input. The likelihood that this will move to the next stage will largely depend on how the achievement at this level is followed up by the organization.

Meanwhile, the level of influence refers to the influence of the stakeholder to the organization for the achievement of middle level 4-6: level 4 (explaining) is the influence in the context of knowledge about organizational decision making, level 5 (placation) is the influence level where the organization listen to the stakeholder's opinion before taking a decision and level 6 (consultation) is the influence level where the stakeholder's input is taken into consideration before organizational decision making. From the answers given, the conclusion is that the stakeholder engagement is still at the middle level: scale 4 (explaining), 5 (placation), and 6 (consultation) out of 12 level. Unlike the achievement of the elements in the audience engagement that is relatively good (except for triggering events), the achievement of stakeholder engagement level in the IIR event is still deemed not good enough. This level of engagement has not reached the desired degrees of involvement nor has showed the sufficient degrees of stakeholder power.

This assessment result on the level of stakeholder engagement is in contrast with the evaluation results on the engagement dimensions that show good results in terms of the element presence in the audience engagement. All elements of participation: audience interest, audience participation and audience feedback, show good results and satisfactory answers from the participants. This brings up a question that on one hand, the dimension of the quality category that can lead to good development of stakeholder engagement of an organization shows a good/high results with the assumption that the right strategy is undertaken, but on the other hand the level of existing stakeholder engagement is still at the middle level.

The researchers then took the effort to dissect the results of interviews with the participants, then compared the results of the evaluation with the existing theory, and came up with the conclusion that the low level is due to the lack of a good implementation of «triggering events» in IIR. This condition created an anti-climax where the high enthusiasm of the participants was not followed up with an activity that ties them emotionally and can seize the opportunity to develop a higher level of stakeholder engagement.

The use of the dialogue format in IIR shows a positive result although the dialogue was interactive and there were different opinion and views from the participants. The general participants expressed their satisfaction with the use of this dialogue format as can be seen from positive responses to the questions regarding the elements of the audience engagement. The researchers believe that the difference of this result depends on the communication style of the event organizer.

\section{CONCLUSIONS AND SUGGESTIONS}

Based on this research, we may draw the following conclusions:

1. Proactive strategy in the form of audience engagement activities plays an important role in building the stakeholder engagement through audience interest, audience participation, audience feedback and triggering events in the activity.

2. IRR activities indicate a high level of audience interest, audience participation and audience feedback, however the followup action was not taken.

3. Triggering events is an important element 
in creating a higher level of engagement between the organization and stakeholders, which will continuously involve stakeholders by communicating further the future actions or activities.

4. A middle level achievement on the activity does not necessarily indicates a bad thing. The understanding of this level of engagement is important for the organization to determine the next step, in accordance with its objectives.

5. Stakeholder satisfaction also indicates the quality level of the generated outcomes, where all outcomes can be linked to decision making within the organization as much as possible. The improvement of the level of stakeholder engagement, in addition to triggering events, can be also attained by achieving all the other three dimensions of stakeholder engagement quality as they determine the strong presence of stakeholder engagement within the organization.

6. The use of two-way dialog format can provide good results which may depend on the communication style of the event organizer.

To improve the results of this research, we suggest to pay attention to the following matters:

1. Any research in similar topic should add a series of elements and factors that may lead to the development of stakeholder satisfaction in terms of creating a stakeholder engagement (timeliness of communication, the honesty and completeness of information, and the empathy and equity of treatment by management).

2. The next related research also needs to explore the factors that can direct the form of two-way dialogue communication into a positive, controlled form of communication and quality-wise can touch into the issues in the dialogue.

3. This research found that triggering events is a relatively determining factor in stakeholder engagement. A further research specializing in this factor to increase the level of stakeholder engagement may be needed.

4. PT PII as the organizer of IIR's audience engagement activities can make improvements in the implementation of stakeholder communication program in order to increase the level of stakeholder engagement, especially in the aspect of triggering events. The enthusiasm of the participants and satisfaction with the execution of the event should be maintained by continuously involve these participants to a specific targeted forum and by using emotionally related media that culminates into an opportunity to "join the force". In addition, the organizers must also show strong commitment in solving the ongoing problems through the means already owned by the organization (the activity web).

5. In the context of two-way dialogue, the communication style of organizer in this activity plays an important role and will determine the success of the dialogue. On one hand, it is an advantage that can be exploited to develop the stakeholder engagement, but on the other hand it is a liability due it high dependency level. 
REFERENCES

Bourne, Dr. Lynda, DPM, PMP, FAIM, (2010). Stakeholder Relationship Management: Using The Stakeholder Circle Methodology For More Effective Stakeholder Engagement Of Senior Management. 7th Project Management National Benchmarking Forum.

Chandra, Herry Pintardi, et.al. (2011). Peran Kondisi Pemangku Kepentingan Dalam Keberhasilan Proyek. Jurnal Manajemen dan Kewirausahaan, Vol 13, No.2, September 2011:135-150.

Clutterbuck, D. (2001). Everyone Needs A Mentor: Fostering Talent At Work. London: CIPD.

Effendy, Onong Uchjana. (2003). Ilmu Komunikasi Teori dan Praktek. Cetakan kesembilanbelas. Bandung : PT Remaja Rosdakarya.

Emshoff, James R. (2001). Managerial Breakthrough Action: Techniques for Strategic Change. New York : Amacom.

Freeman, R.E. (1984). Strategic Management: A Stakeholder Approcah. Boston: Pitman.

Freeman, R.E., McVea, J. (2001). A stakeholder approach to strategic management. In: Hitt, M., Harrison, J., Freeman, R.E. (Eds.), Handbook of Strategic Management. Oxford : Blackwell Publishing.

Friedman L. Andrew and Samantha Miles. (2006). Stakeholders Theory and Practice, Oxford University Press.

Isenmann, R., \& Kim, K.-C. (2006). Interactive sustainability reporting. Developing clear target group tailoring and stimulating stakeholder dialogue. In M. B. a. R. B. S. Schaltegger (Ed.), Sustainability Accounting and Reporting (pp. 533-555). Berlin: Springer.

Manetti, G. (2011). The quality of stakeholder engagement in sustainability reporting: empirical evidence and critical points. Corporate Social Responsibility and Environmental Management 18, pp. 110-122.

Smith, D.Ronald. (2013). Strategic Planning for Public Relations. New York: Routledge.

Yang, J., et.al. (2011). Stakeholder management in construction: An empirical study to address research gaps in previous studies. International Journal of Project Management, 29(7), 900-910.

Zadek, S. and Raynard, P. (2002). Stakeholder Engagement: Measuring and Communicating the Quality. Accountability Quarterly 19, pp. 8-17. 